\begin{tabular}{|c|c|}
\hline Title & $\begin{array}{l}\text { Th1-Mediated Intestinal Inflammation in Crohn's Disease May Be Induced by Activation of } \\
\text { Lamina Propria Lymphocytes Through Synergistic Stimulation of Interleukin-12 and } \\
\text { Interleukin-18 Without T Cell Receptor Engagement. }\end{array}$ \\
\hline Sub Title & $\begin{array}{l}\text { クローン病におけるThlを介する腸管炎症はT細胞受容体の会合を要さずにInterleukin-12とInterle } \\
\text { ukin-18の協調的な刺激による粘膜固有層リンパ球の活性化によって誘導される }\end{array}$ \\
\hline Author & 岡沢，啓(Okazawa，Akira) \\
\hline Publisher & 慶應医学会 \\
\hline Publication year & 2004 \\
\hline Jtitle & 慶應医学 (Journal of the Keio Medical Society). Vol.81, No.1 (2004. 3),p.21- \\
\hline \multicolumn{2}{|l|}{ JaLC DOI } \\
\hline \multicolumn{2}{|l|}{ Abstract } \\
\hline Notes & 号外 \\
\hline Genre & Journal Article \\
\hline URL & $\begin{array}{l}\text { https://koara.lib.keio.ac.jp/xoonips/modules/xoonips/detail.php?koara_id=AN00069296-2004030 } \\
\text { 2-0021 }\end{array}$ \\
\hline
\end{tabular}

慶應義塾大学学術情報リポジトリ(KOARA)に掲載されているコンテンツの著作権は、それぞれの著作者、学会または出版社/発行者に帰属し、その権利は著作権法によって 保護されています。引用にあたっては、著作権法を遵守してご利用ください。

The copyrights of content available on the KeiO Associated Repository of Academic resources (KOARA) belong to the respective authors, academic societies, or publishers/issuers, and these rights are protected by the Japanese Copyright Act. When quoting the content, please follow the Japanese copyright act. 


\title{
Th1-Mediated Intestinal Inflammation in Crohn's Disease May Be Induced by Activation of Lamina Propria Lymphocytes Through Synergistic Stimulation of Interleukin-12 and Interleukin-18 Without T Cell Receptor Engagement.
}

\author{
(クローン抦におけるTh1を介する郮管炎症はT細胞受谷体の会合を要さずにInterleukin-12と \\ Interleukin-18の協調的な刺激による粘膜间有層リンパ球の活性化によって誘煘される)
}

岡沢啓

\section{内容の要旨}

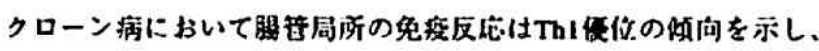
IL-12、IL-18の閉与が報告されている。IL-12とIL-18は、CD4隐住T

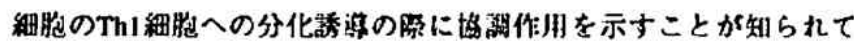

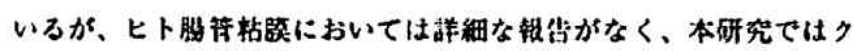

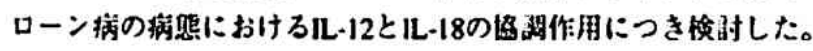

そこで本研究ではまず、クローン病15例、趾常者 6 例の未梢血佔

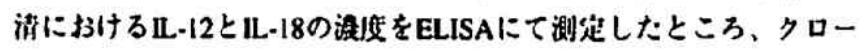
ン萮において再者ともに有意に高值を示し、かつ両者の浱度は有意

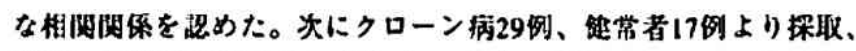

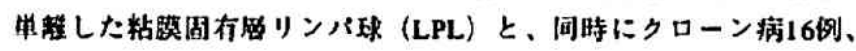

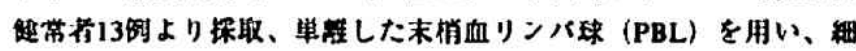
胞表而の受容体の発現をフローサイトメトリーにて矮析したところ、

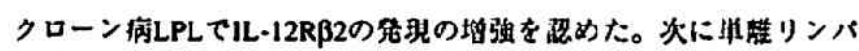

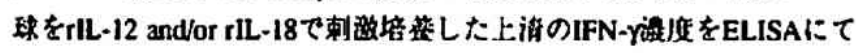

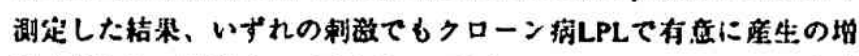

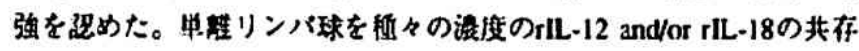

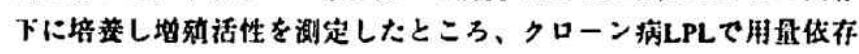

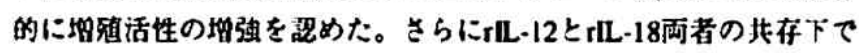

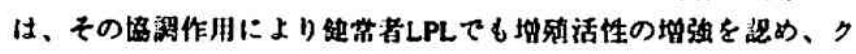

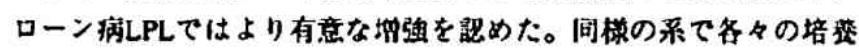
浓に中和抗体を唀加したところ、期常者LPLでは抗IL-2抗体あるいは

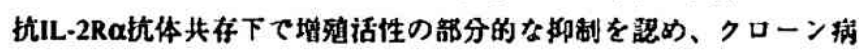

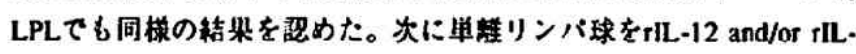
18の其存下て培萑し、細胞表面の受容体の先现をフローサイトメト

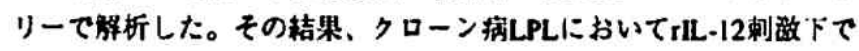

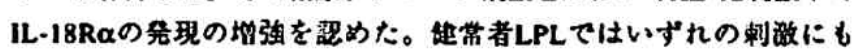

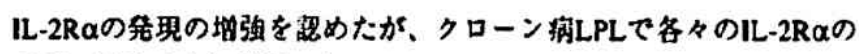
発周の间強はより著明であった。

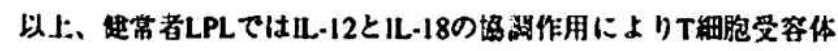

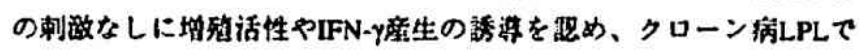
それらが有意に珮强されることを示した。クローン郎LPLではIL-

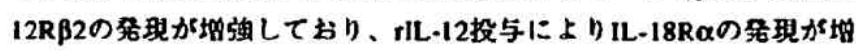

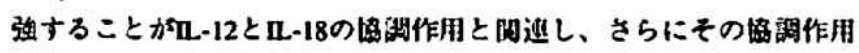
にはIL-2/L-2Rの城殖シタナルが閉与していると考えられた。IL-12

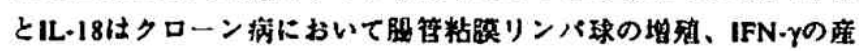

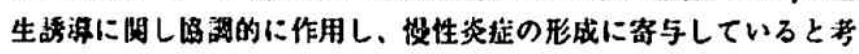
えられた。

\section{踚文察查の要旨}

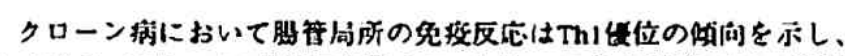

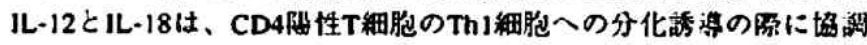

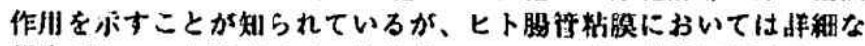

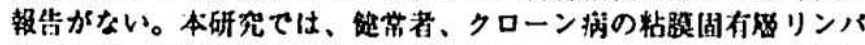

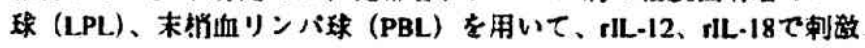
培筑し、フレーサイトメトリーにて細胞紧面の受容体の発现、

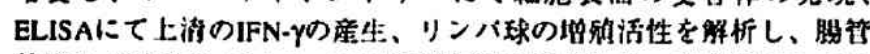

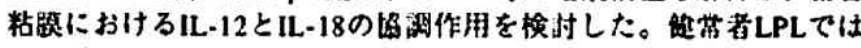

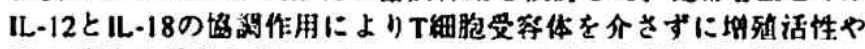

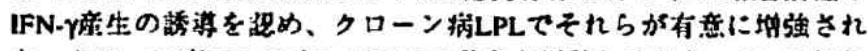

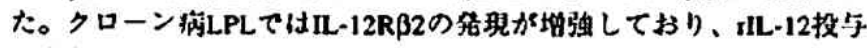

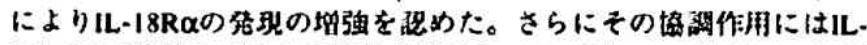

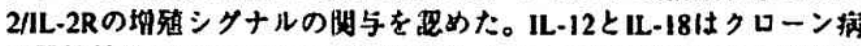

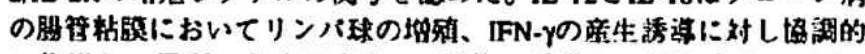

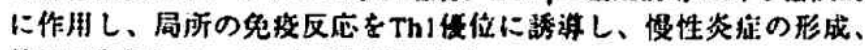
持䍃に条与していることが示咬された。

筷植ではPLとPBLの組成につき、特にNK細胞なとの混人につき 面問された。それに对して、LPLに閏してはフローサイトメトリー

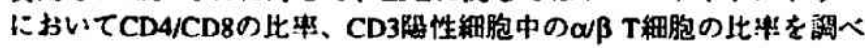
ているが、マクロファージやNK細胞の湜人はあると考えられ、特に

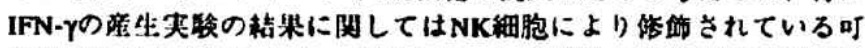

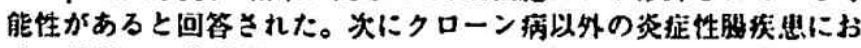

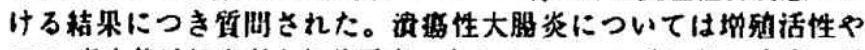

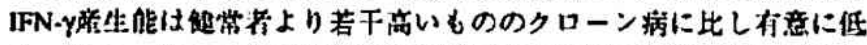
く、また、リンパ球の細胞表面の受容体の発现の粘果に間してはク ローン赫に特簧的であると回答された。また、同一個体における炎

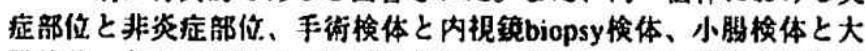

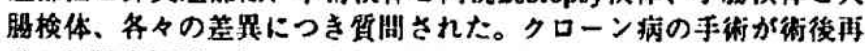

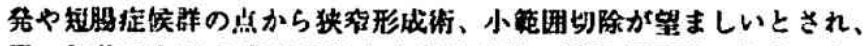
同一個体における炎拉部位と非炎症部位の妳取が困准であること、

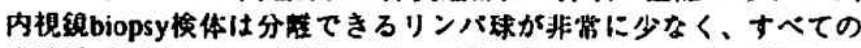

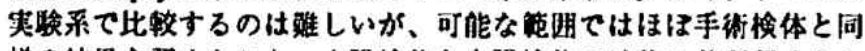

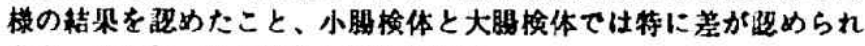
なかったこと、以上が各々回答された。

以上、本研究はさらに険郡すべき橦题を残しているが、クローン

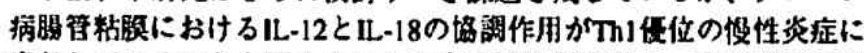
寄与していることを㽗らかにした点で消化器挤学上、有意接な研究 であると粭価された。

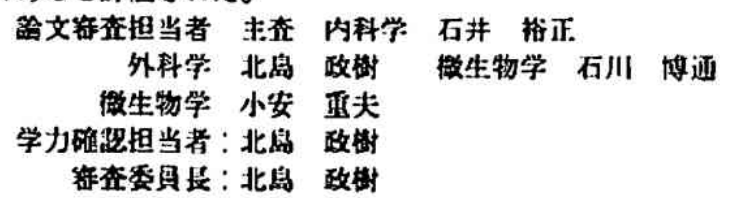

試間旧：平成15年12月27日 